\title{
好酸球浸潤のみられた口腔扁平上皮癌症例について
}

\author{
五十嵐智一・浦出雅 裕・杉 政 和・浜田傑 \\ 且井誠・白砂兼光・宮崎正

\section{Oral squamous cell carcinoma with eosinophilic infiltration}

\author{
Tomokazu Igarashi • Masahiro Urade - Masakazu SugI \\ Suguru Hamada - Makoto Usui - Kanemitsu Shirasuna \\ Tadashi MrYAZAKI
}

\begin{abstract}
Blood eosinophil and eosinophilic infiltration of tumor tissues in patients with oral squamous cell carcinoma and no allergic diseases were investigated. The patients with blood eosinophilia $(>6.0 \%)$ were $10 / 85(11.8 \%)$, and the patients showing increase of $\%$ blood eosinophil more than $5 \%$ as compared to that of the preirradiated state within 2 months postrirradiation were $20 / 72(27.8 \%)$. On the other hand, high grade eosinophilic infiltration ( $>50$ cells in $400 \times$ field) to tumor tissues was observed in $7 / 76$ of biopsy specimens and in $3 / 50$ of operated materials.

In a case with eosinophilia and eosinophilic infiltration of both biopsy and operated materials, the correlation of eosinophilia with tumor growth and regression was strongly suggested.

These results indicate that although eosinophilia is induced by oral cancer as well as irradiation, tumor cells may produce an eosinophil chemotactic factor (ECF) in tumor-induced eosinophilia.
\end{abstract}

Key words: oral squamous cell carcinoma, eosinophilic infiltration

緒

言

末梢血中に好酸球の增加する，いわゆる好酸球增多症 の原因として，喘息，尋麻疹などのアレルギー疾患，寄 生虫感染, 尋常性天疮瘡やへルペス性皮虚炎などの皮嗵 疾患があげられるが，悪性腫瘍や放射線照射後にもみら れることが知られている1 5) 特に，悪性腫痬と好酸球 增多に関しては，古くからいくつかの報告がみられるに もかかわらず，その因果関係は不明であった。近年, Wasserman $5^{6)}$ や, Goetzl ら〕により, 腫焬細胞から 好酸球の遊走を促す因子 (eosinophil chemotactic factor, ECF）が㦃生されていることが明らかにされたことか

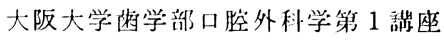

（主任：宮崎 正教授）

The first Department of Oral and Maxillofacial Surgery, Osaka University Faculty of Dentistry (Chief: Prof. Tadashi Miyazaki)

受付日：昭和60年 1 月 24 日
ら, ECF のもつ生物学的のみならず，臨床的意義につ いても注目されつつある。著者らも，ECF を産生して いることが強く示唆される下顎煰症例に遭遇したのを契 機に，当科を受診した口腔扁平上皮癌85症例に対して， 末梢血护よび生検, 手術摘出物中の腫瘍組織における好 酸球存在の有無, さらに放射線治療, 化学療法や外科治 療と好酸球の動態を retrospective に検討したので，上 記の興味ある症例と併せて報告する。

\section{対象および方法}

最近 5 年間に当科を受診し，病理組織学的に扁平上皮 癌と確定診断された症例のらち，明らかなフレルギー疾 患, 皮厝疾患をもたず，臨床検查結果，生検標本，手術 摘出標本の整った85症例を調査対象とした。

末梢血好酸球の正常籁囲は，諸家の報告により多少異 なるか，白血球百分率に㙏いて，1〜 5\%（絶対数 100〜 $400 / \mathrm{mm}^{3}$ ) の範囲におさまることから，6\%以上を好酸 球增多症例とした。 


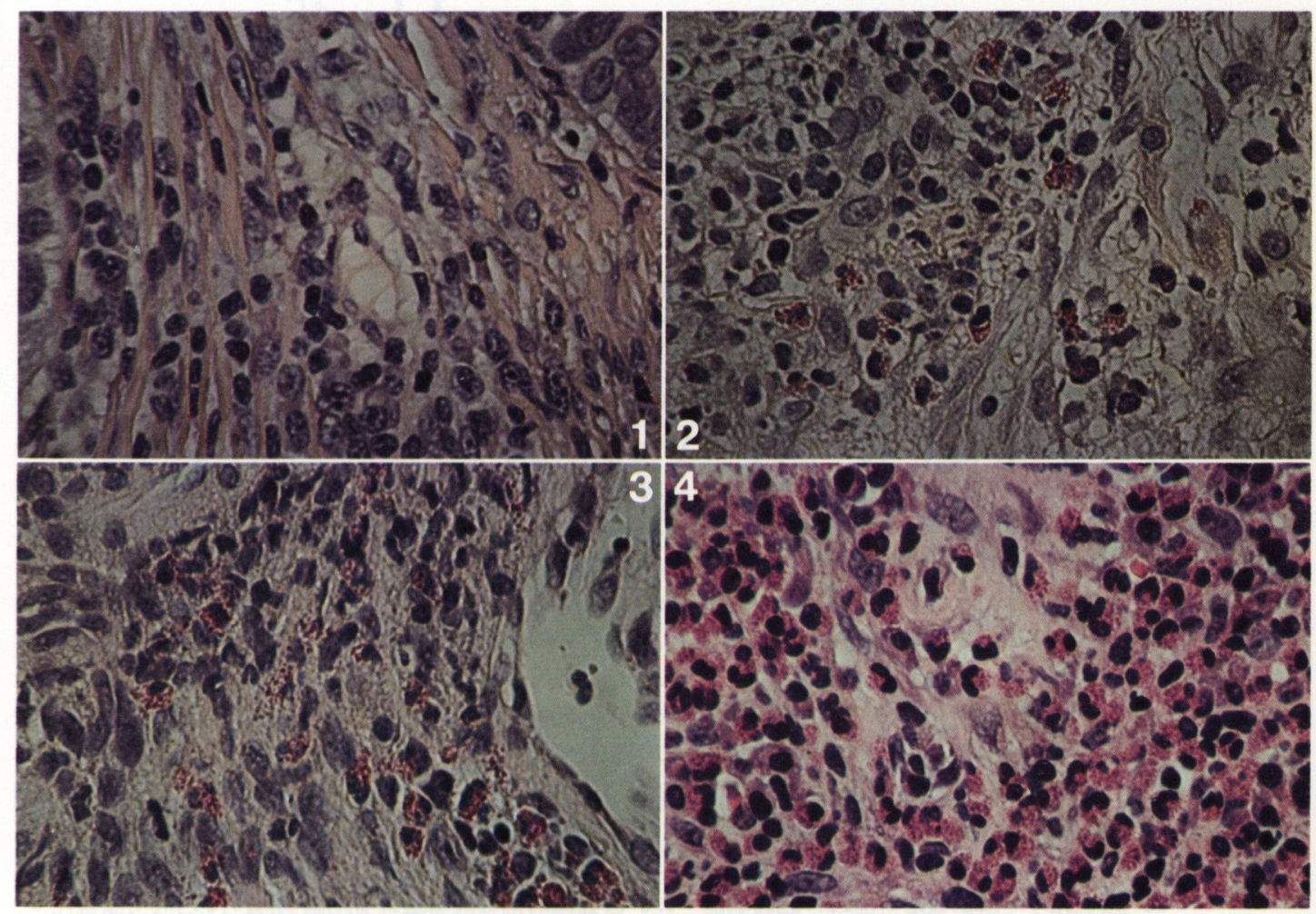

写真 1 腫瘍組織における好酸球浸潤の程度

H-E 染色標本を, 400 倍視野で検鏡し，好酸球数を算定した。

1: Grade 1, 2 : Grade 2 (軽度浸潤), 3: Grade 3 (中等度浸潤), $4:$ Grade 4 (高度浸潤)

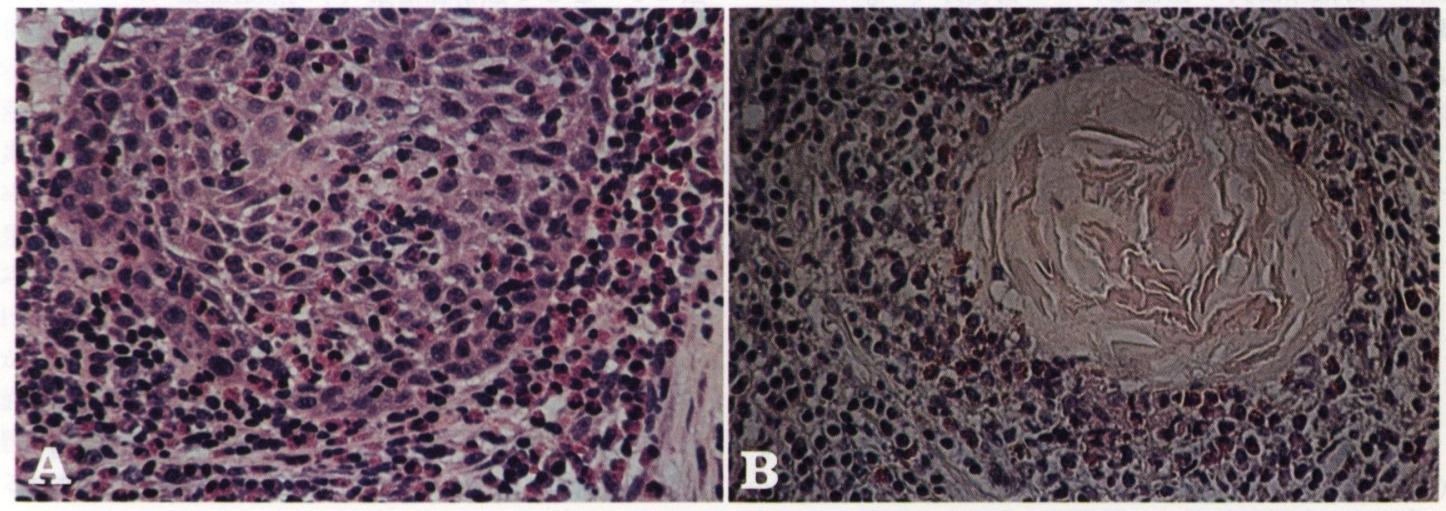

写真 $2 \mathbf{A}$ : 腫瘍胞巣内に浸潤した好酸球 $(\mathrm{H}-\mathrm{E}$ 染色， $\times 200)$

B：リンパ節転移腫瘍胞巣周囲に浸潤した好酸球 $(H-E$ 染色， × 200) 
表 1 生検組織中の好酸球浸潤

\begin{tabular}{rrr}
\hline Grade 1 & 38 & $(50.0 \%)$ \\
Grade 2 & 17 & $(22.4 \%)$ \\
Grade 3 & 14 & $(18.4 \%)$ \\
Grade 4 & 7 & $(9.2 \%)$ \\
\hline
\end{tabular}

表 2 摘出物組織中の好酸球浸潤

\begin{tabular}{rrr}
\hline Grade 1 & 37 & $(74.0 \%)$ \\
Grade 2 & 6 & $(12.0 \%)$ \\
Grade 3 & 4 & $(8.0 \%)$ \\
Grade 4 & 3 & $(6.0 \%)$ \\
\hline & 50 & $(100.0 \%)$ \\
\hline
\end{tabular}

表 3 末梢血好酸球增多および腫瘍組織の高度好酸球浸潤のみられた症例一筧

\begin{tabular}{|c|c|c|c|c|c|c|c|}
\hline 症 & 例 & \multicolumn{2}{|c|}{ 年齡性別 } & TNM 分類 & $\begin{array}{l}\text { 初診時末梢血中 } \\
\text { の好酸球百分率 } \\
\% \text { (白血球数) }\end{array}$ & $\begin{array}{c}\text { 生検組織中 } \\
\text { の好酸球数 } \\
\text { 個/hpf }\end{array}$ & $\begin{array}{c}\text { 摘出物組織中 } \\
\text { の好酸球数 } \\
\text { 個/hpf }\end{array}$ \\
\hline 1 & & 66 & $\mathrm{~F}$ & T4N2M0 & $12.7(3,900)$ & 60 & $>174$ \\
\hline 2 & & 51 & M & T4N3M0 & $9.0(5,900)$ & 算定不能 & $(-)$ \\
\hline 3 & & 71 & $\mathrm{~F}$ & T4N0M0 & $6.0(4,200)$ & 25 & $(-)$ \\
\hline 4 & & 69 & $F$ & T2NOMO & $15.0(3,700)$ & 63 & $(-)$ \\
\hline 5 & & 76 & M & T4N0M0 & $30.0(12,000)$ & $(-)$ & 手術行わず \\
\hline 6 & & 52 & M & T3N0M0 & $10.0(7,200)$ & $(-)$ & $(-)$ \\
\hline 7 & & 53 & M & T3N0M0 & $6.0(7,200)$ & 15 & 手術行わず \\
\hline 8 & & 50 & M & T2N0M0 & $8.2(4,800)$ & 38 & 手術行わず \\
\hline 9 & & 85 & M & T2NOM0 & $8.0(4,500)$ & $(-)$ & $(-)$ \\
\hline 10 & & 47 & M & T3N1M0 & $16.0(11,000)$ & 算定不能 & $(-)$ \\
\hline 11 & & 43 & $\mathrm{~F}$ & T1N0M0 & $0(4,300)$ & 67 & 手術行わず \\
\hline 12 & & 48 & M & T3N1M0 & $2.0(7,000)$ & 50 & $(-)$ \\
\hline 13 & & 55 & M & T2N0M0 & 1. $0(4,500)$ & 算定不能 & 手術行わず \\
\hline 14 & & 70 & $\mathrm{M}$ & T4N3M0 & $2.4(5,500)$ & 7 & 84 \\
\hline 15 & & 73 & $\mathbf{F}$ & T3N0M0 & 3. $0(6,300)$ & $(-)$ & $>100$ \\
\hline
\end{tabular}

病理組織学的には, 生検標本, 手術摘出標本とも, 組 織中の好酸球浸潤の程度を，400 倍視野 (High-Power Field, hpf）で少なくとも5 視野検鏡した。腫瘍組織中 あるいは，その周辺にみられる好酸球浸潤は，一様に分 布しておらず，局在性があることがスクリーニングで明 らかとなったため，5視野中，最も多い好酸球数をもっ て表した.

$$
\text { 結果 }
$$

\section{1. 末梢血中に好酸球增多を認めた扁平上皮癌症例に ついて}

初診時に好酸球增多を認好た症例は，85 例中 10 例 (11.8\%) で，好酸球百分率 6〜30\%に分布していた。 治療経過中，特に放射線照射後に継発する好酸球增多症 は，造血臓器を含む領域に広範囲に照射された場合に多 く報告されて扣り，頭頸部領域ではまれであるとされて いるが2,8)，85 例中, コバルト60による術前外部照射(平
均照射線量 2,940 rad) あるいは上顎洞癌で三者併用療 法の 1 つとて放射線治療 (平均照射線量 4,780 rad) を行った症例は，それぞれ60例，12例の計72例で，その らち照射期間中から照射終了後 2 か月以内に末梢血好酸 球百分率が，照射前のそれより $5 \%$ 以上上昇した症例ば 20 例 $(27.8 \%$ ) であった.さらに, そのなかで照射後の好 酸球百分率が $10 \%$ を越えた症例は 8 例で，最大は $28 \%$ に 上昇した。初診時に好酸球增多を認めた10例中 6 例は， 放射線照射によりむしろ減少する傾向を示し，上昇した のは 3 例のみであった。

\section{2. 腫瘍組織における好酸球浸潤}

生検および手術摘出物標本を, 方法で述べたように, 400 倍視野で検鏡し, 腫瘍胞巣あるいは胞巣周囲の好酸 球浸潤の程度を便宜的に以下の 4 段階に分類した（写真 1).

Grade 1 ; 好酸球浸潤をまったく認めない.

Grade 2 (軽度浸潤)； 1 24 個/hpf

Grade 3 (中等度浸潤)；25～49 個/hpf 


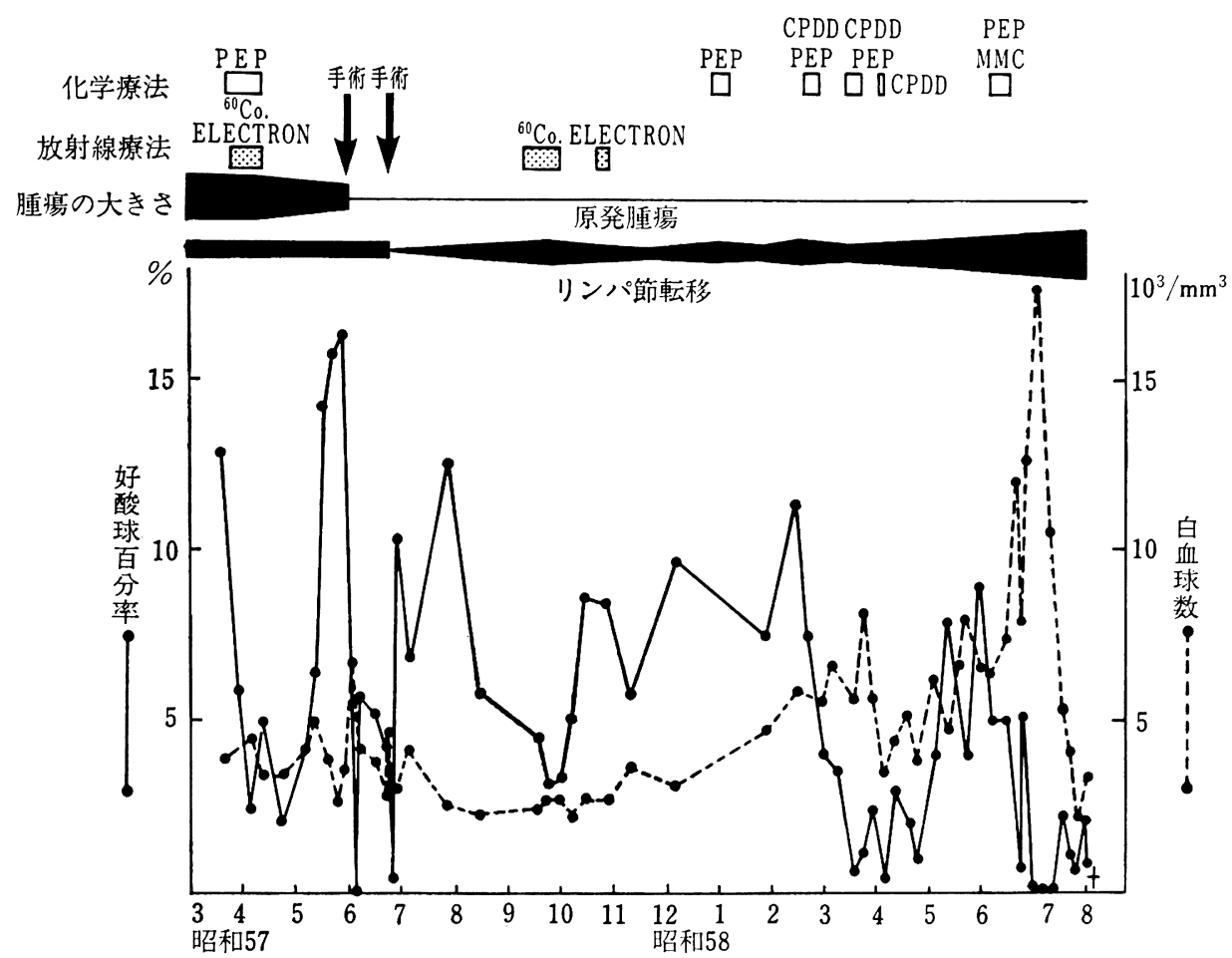

図 1 症例 1 に扣ける治療経過と末梢血好酸球の動態

Grade 4 (高度浸潤)； 50 個以上/hpf

この規準に従って，85症例中，当科で初診時に生検を 施行した 76 症例, さらにそのうち術前照射後に腫瑝摘出 を行った症例および上㴿洞癌で三者併用療法を行ったの ち, 病理組織検查を施行した症例50例について, 腫瘍組 織中の好酸球浸潤をまとめて表 $1 ， 2$ に示した。生検組 織中および摘出物組織中の好酸球浸潤が Grade 4 を示 したものは，それぞれ 7 例と 3 例であった。これらの症 例を, 末梢血の好酸球增多を認めた 10 例とともに表了に 示した。 末梢血好酸球増多を認め, 生検組織中の好酸球 浸潤も高度であった症例は，症例 $1 ， 2 ， 4 ， 1004$ 例で あり，そのらち摘出物組織中にも高度の好酸球浸潤を認 めた症例は, 症例 1 のみであった。症例11，12，13では， 生検組織中のみに，また症例14，15では摘出物組織中の

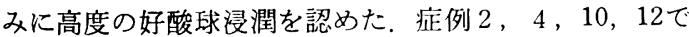
は，初診時生検組織中には高度の浸潤がみられたにもか かわらず，摘出物では消失していた，組織中にみられる 好酸球浸潤の多くは, 腫瘍胞巣周囲に顕著であったが, 腫瘍胞巣内あるいはリンパ節枟移腫塬胞栄周柬にみられ る症例もあった（写真 2).

$$
\text { 症 }
$$

66歳 女性.
初 診：昭和57年 3 月

臨床診断：左側下罘嘪肉癌, T4N2M0.

既往歴・家族歴：特記すべきことなし，

経 過：某䓱科にて搔爬をうけたため, 初診時には,

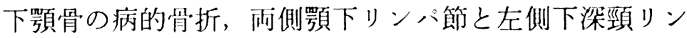
ハ節に，それぞれ示指頭大と小指頭大のりンハ節転移を 認めた扁平上皮癌の進展症例であった。図 1 に示すよう に, 一次治療として, 原発栄抢よび雨側䫕下リンパ節に, コバルト 60 (総線量 $2,800 \mathrm{rad} / 14 \mathrm{f}$ ), 左側頸部リンパ節 に, 電子線（総線量 $2,800 \mathrm{rad} / 14 \mathrm{f}$ ) の外部照射と, ペ プレオマイシン（PEP；総投与量 $90 \mathrm{mg}$ ）静注を併用し たのち, 左全頸部郭清術, 下買骨半側切除を含む隀瘍摘 出術，D-P 皮少による即時再建を行った。ささらに D-P 皮升切離之同時に，右上頸部郭清術を施行した。初診 時，末梢血好酸球百分率は $12.7 \%\left(\mathrm{WBC} 3,900 / \mathrm{mm}^{3}\right.$ ) で好酸球增多を示し，生検組織中に批いても，好酸球浸 潤は Grade 4 であった（表了）。これら好酸球浸潤の様 相は，腫腸間質のすべてに一様に浸潤しているのではな く, 局在性があり, 一部には, 腫瘍胞栄内に浸潤してい る像も認められた。術前外部照射と化学療法による畽㻛 の縮少は藷明で，末梢血好酸球は，正常範囲内にまで急 激に減少したが，外部照射終了後 1 か月頃より再び急激 な好酸球增多を認め, 手術直前の 5 月 28 日には，好酸球 百分率 $16.4 \%\left(\mathrm{WBC} 3,500 / \mathrm{mm}^{3}\right)$ となった。約 2,000 
$\mathrm{ml}$ の輸血を行った手術直後の 6 月日日には, $0 \%$ (WBC $\left.6,700 / \mathrm{mm}^{3}\right)$ と，一時的に著明に減少したが，2 日後に は，正常範囲内で上昇した。摘出物の病理組織標本にお ける好酸球浸潤も Grade 4 であったが, 生検時よりも さらに著明であった（表了）。また左側下深頸りンパ節 転移巣の周囲にも好酸球浸潤が観察された。術後の経過 は順調で, 7 月日日退院し, 外来にて経過観察を行っ ていたが，8月下旬より右靧下部の腫脹を認め, 試験切 除の結果, 再発が確認された。再発巣に対し、コバルト 60 (3, 850 rad/11 f) と, 電子線 $(1,500 \mathrm{rad} / 3 \mathrm{f})$ による 外部照射を施行し，一時的に增殖が扰さえられる傾向を 認めたものの，11月末には再び増殖著明となった，その ため, 再入院し, 昭和58年 2 月下旬より 4 月上旬にかけ て, シスブラチン (CPDD) と PEP の併用化学療法を 3 クール施行したところ, 各クールごとに腫瘍の一時的 縮小を求めたが，徐々に增大傾向を示した。6月中旬 に, PM 療法を施行した頃より, 全身状態の悪化ととも

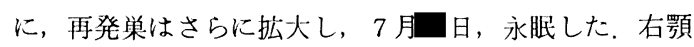
下部再発後の末梢血好酸脙百分率は, 放射線治療, 化学 療法により整時, 減少を示したが, 腫瘍の消長に伴って 変動する傾向を示し，2月日には $11.4 \%$ (WBC 5, 900/ $\mathrm{mm}^{3}$ ) に達した。末期には，白血球数は著明に增加した にもかかわらず，好酸球はほとんど消失した。この間， 原発巣および左侧橮部には再発を認めなかった。

\section{考}

察

従来より，好酸球增加は，アレルギー将患や等生虫病 変の存在を示唆する有力な臨床的指摽となってきたが, 好酸球そのものが果たす役割については，な打不明な点 が多い.

嗹瑒組織の好酸的浸潤も，これまでは間質反応のひと つとして捉えられてきたが，1974 年に Wasserman ら6) が, 肺の大細胞性扇平上皮嵒組織抽出液中に, 好酸球遊 走因子 (ECF) が存在することを見い出し，ECF-Ca と 名づけて以来，同様の因子がつぎつきと発見され，悪性 腫境と好酸球の関係に新しい概念が確立されつつある。 上記の ECF-Ca は, Goetzl らによるその後の解析によ り, 患者の尿や細胞培養上清中にも産生され, アナフ ラキシーの際に見い出される ECF-A とは, 明らかに異 なる因子であることが証明され，ECF-LSC (MW 300〜 400) と命名された7) さらに，1979 年には，組織球性 リンパ腫の患者から ECF-HL（MW 4,000～5, 000） が, 1982 年には, 子宮頸癌の患者から ECF-CC (MW 12,500）が分離されたことが報告されている11 13)。これ らの患者では，いずれも末梢血の好酸球增多を認め, 腫 瘍の切除とともに好酸球数が減少し, 再発や転移にとも なって增加するといら，腫瘳の消長を反咉した動態を示 した。このような好酸球浸潤が腫場組織内に藷明に(400
倍視野で 100 個以上）みられる頻度について, 井上らの 報告 ${ }^{22}$ している子宮頸癌進展例では, 778例中171例（22

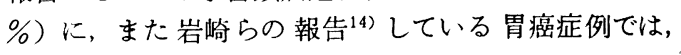
647例中157例 $(24 \%)$ といら高率にみられ, しか子後者 では，その $61 \%$ \%分化癌で，好酸球浸潤症例は予後良 好であったと報告されている。

そこで今回, 著者らは, 口腔癌における好酸球浸潤症 例について検討した，その結果，末梢血中に好酸球增多 を認める症例は85例中10例（11.8\%）であったが，生検 組織76検体, あるいは手術摘出物組織50検体中の好酸球 浸潤が 400 倍視野で 100 個以上の症例は， 5 例のみで, 万ち 2 例は末梢血好酸球增多を認めなかった。 ゆえに, 口腔癌に打ける好酸球浸潤例は, 必ずしも未梢血好酸球 增多と並行しておらず，上記の報告例に比べるとかなり 少数であり, 全く好酸球浸潤を認めない症例が, 生検組 織で50\%，摘出物組織で74\%を占めた。 そのため, 本研 究では, 組織中の好酸球浸潤の程度を, 400 倍視野で 50 個以上を高度， $25 \sim 49$ 個を中等度， $1 \sim 24$ 個を軽度と した。 末梢血好酸球增多, 生検組織, 手術摘出物組織共 に高度の好酸球浸潤を認めた症例 1 は, 癌治療に上る腫 瘍の縮小, 転移形成に相応して末梢血好酸球百分率が变 動したことが示唆される稀な症例と考えられる. 頸部転 移腫埸が著明に增大した末期に至って, 白血球增多がみ られたにもかかわらず，好酸球がほとんど消失した理由 は不明であるが, いわゆる悪夜質によるものか, 呼吸器 感染による著明な好中球增加に伴う代償性の好酸球减少 あるいは, 肺線維症子防のために投与されたステロイド 剂の影響とも考えられる ${ }^{17)}$.

好酸球增多をひき起こす他の原因として, 放射線照射 があげられており，頭頸部領域では稀とされながらも， これまで本邦でも2 例が報告されており ${ }^{15,16)}$ ，らち1例 は表 3 の症例10である。頭頸部癌の治療では, 放射線治 療が単独あるいは併用されることが多く, 腫㻛細胞によ る ECF 産生を論ずる場合, 当然検討が必要となる。放 射線照射による好酸球增多は, 大半が照射終了後 2 か月 以内に起こって括り，その頻度は72例中20例 (27.8\%) で, 万ち 8 例が好酸球百分率10\%を越えた。この結果か らすると，口腔癌に打いても少なからず，放射線照射に より末梢血好酸球の增加が意起されると考えられる。 し かし照射後 $1 \sim 2$ か月後に外科的に切除された腫瘍組織 中には, 少数の例外を除いて, むしろ生検組織より好酸 球浸润が減少していること, 腫瑒胞巣中あるいは, リン 八節転移腫瑝胞巣周囲に, 局在性に好酸球浸潤がみられ る症例のあること, 症例 1 のよらに腫瑝の消長に伴って 好酸球百分率が变動するといら事実は, 口腔癌において も隀瑒細胞が ECF を産生する可能性を強く示㖫するる のと考えられる。ささらに, 腫瘍細胞による ECF 産生は, 局所的なもので，末梢血好酸球数にまで影響を执よぼす ことは少ないと思われる。 
今回の検討では，残念ながら好酸球浸潤症例が少なか ったため，予後にまで言及することができなかったし， 腫瘍組織から ECF を抽出する機会も得られなかった。 今後とも, この興味深い現象をさらに検索するととも に, 口腔癌の子後判定の一指標となる可能性が明らかに されねばならない。

結

語

明らかなアレルギー疾患をもたない口腔扁平上皮癌 85 症例に対して，末梢血好酸球百分率，生娭および手術摘 出物組織中の好酸球浸潤を検討し, 以下の結果を得た.

1）末梢血好酸球百分率 $6 \%$ 以上の症例は，85例中 10 例 $(11.8 \%)$ で，そのうち放射線治療を受けた症例72例 中20例 $(27.8 \%)$ は照射後 2 か月以内に，照射前より 5 $\%$ 以上の上昇を認めた。

2) 腫瘍組織中に高度の好酸球浸潤（400 倍視野で 50 個以上）を示した症例は，生検組織76例中 7 例 $(9.2 \%)$, 手術摘出物組織 50 例中 3 例 (6.0\%) で必ずしも末梢血 好酸球增多を示した症例と一致しなかった。

3 ）末梢血好酸球增多と生検および摘出物組織に高度 の好酸球浸潤を示した 1 症例では, 癌治療による腫瘍の 消長を反映して末梢血好酸球百分率が変動することが示 唆された。

以上の結果から，口腔癌に打いても，放射楾照射によ って若起される好酸球增多症例もあるが，腫瘍細胞によ る好酸球遊走因子の産生が, 強く示唆される症例もある と考えられる。

\section{引用文 献}

1) Wintrobe, M.M.: Clinical Hematology. 7 th Ed, Lea and Febiger, Philadelphia, 1974, p 1283-1286.

2) Muggia, F.M., Ghossein, N.A., et al.: Eosinophilia following radiation therapy. Oncology 27: 118-127 1973.

3) Ghossein, N.A. and Stacey, P.R.T.. The prognostic significance of radiation-related eosinophilia. Radiology 107: 631-633 1973.

4) Ghossein, N.A., Boseorth, J.L., et al.: Radiation-related eosinophilia. Radiology 117: 413-
4171975.

5) Isaacson, N.H. and Rapoport, P.: Eosinophilia in malignant tumors: Its significance. Ann Intern Med 25: 893-905 1946.

6) Wasserman, S.I., Goetzl, E.J., et al.: Tumorassociated eosinophilotactic factor. N Engl J Med 290: 420-424 1974.

7) Goetzl, E.J., Tashjian, A.H., et al.: Production of a low molecular weight eosinophil polymorphonuclear leukocyte chemotactic factor by anaplastic squamous cell carcinomas of human lung. J Clin Invest 61: 770-780 1978.

8) Kurohara, S.S., Hempelmann, L.H., et al.: Eosinophilia after exposure to ionizing radiation. Radiation Res 23: 357-368 1964.

9) Kay, A.B. and Austen, K.F.: The IgE-madiated release of an eosinophil leucocyte chemotactic factor from human lung. J Immunol 107: 899-902 1971.

10) Wasserman, S.F., Goetzl, E.J., et al.: Preformed eosinophil chemotactic factor of anaphylaxis. J Immunol 112: 351-358 1974.

11) Goetzl, E.J., Rothenberg, J., et al.: A novel eosinophil chemotactic factor derived from a histiocytic lymphoma of the central nervous system. Clin Exp Immunol 40: 249-255 1980.

12) Inoue, T., Iwasaki, K., et al.: Cervical carcinoma and eosinophil. I. Eosinophil chemotactic factor derived from invasive cervical carcinoma with eosinophil infiltration. Clin Immunol Immunopathol 21: 320-331 1981.

13）井上武夫, 千原勤, 他“一子宮缅癌の好酸球性 間質反応と頙癌由来好酸球遊走因子。東海産科 婦人科学会雑誌 19: 1-8 1982.

14）岩崎一教, 井上武夫, 他: 高度好酸球浸潤を伴 5 胃瘦患者における好酸球の臨床的意義につい て。第43回日本癌学会総会記事：1301984.

15）三木浩三，松村智弘，他：放射線療法により著 明な好酸球の増多をきたしたと考えられる 1 症 例。 日口外誌 24: 549-552 1978 .

16) Sato, M., Yoshida, H., et al. Carcinoma of the maxillary sinus with eosinophilia. Int $\mathrm{J}$ Oral Surg 10: 62-67 1981.

17) Wintrobe, M.M.: Clinical Hematology. 7 th Ed, Lea and Febiger, Philadelphia, 1974, p 262-263. 